\title{
Differential regulation of pig theca cell steroidogenesis by LH, insulin-like growth factor I and granulosa cells in serum-free culture
}

\author{
E. M. Shores ${ }^{1}$, H. M. Picton ${ }^{2}$ and M. G. Hunter ${ }^{1}$ \\ ${ }^{1}$ Division of Animal Physiology, School of Biological Sciences, University of Nottingham, Sutton Bonington Campus, Loughborough, \\ Leicestershire LE12 5RD, UK; and '2Centre for Reproduction, Growth and Development, Division of Obstetrics and Gynaecology, \\ University of Leeds, Clarendon Wing, Leeds General Infirmary, Belmont Grove, Leeds LS2 9NS, UK
}

\begin{abstract}
The regulation of pig theca cell steroidogenesis was studied by the development of a physiological serum-free culture system, which was subsequently extended to investigate potential theca-granulosa cell interactions. Theca cells were isolated from antral follicles $6-9 \mathrm{~mm}$ in diameter and the effects of plating density $\left(50-150 \times 10^{3}\right.$ viable cells per well), LH (0.01-1.0 $\left.\mathrm{ng} \mathrm{ml}^{-1}\right)$, Long R3 insulin-like growth factor I (IGF-I) (10, $\left.100 \mathrm{ng} \mathrm{ml}^{-1}\right)$ and insulin $\left(1,10 \mathrm{ng} \mathrm{ml}^{-1}\right)$ on the number of cells and steroidogenesis were examined. The purity of the theca cell preparation was verified biochemically and histologically. Co-cultures contained $50 \times 10^{3}$ viable cells per well in granulosa to theca cell ratio of 4:1. Wells containing granulosa cells only were supplemented with 'physiological' doses of androstenedione or $100 \mathrm{ng} \mathrm{ml}^{-1}$. Oestradiol production by cocultures was compared with the sum of the oestradiol synthesized by granulosa and theca cells cultured separately. Oestradiol and androstenedione production continued throughout culture. High plating density decreased steroid production $(P<0.01)$. LH increased androstenedione $(P<0.001)$ and oestradiol $(P<0.05)$ synthesis and the sensitivity of the cells increased with time in culture. Oestradiol production was increased by $10 \mathrm{ng}$ IGF-I ml-1 $(P<0.001)$ but androstenedione required $100 \mathrm{ng} \mathrm{ml}^{-1}$ $(P<0.001)$. Co-cultures produced more oestradiol than the sum of oestradiol synthesized by theca and granulosa cells cultured separately $(P<0.001)$, irrespective of the androstenedione dose. This serum-free culture system for pig theca cells maintained in vivo steroidogenesis and gonadotrophin responsiveness. Thecal androstenedione and oestradiol production were differentially regulated and were primarily stimulated by LH and IGF-I, respectively. Theca-granulosa cell interactions stimulated oestradiol synthesis and this interaction was mediated by factors additional to the provision of thecal androgen substrate to granulosa cells.
\end{abstract}

\section{Introduction}

Although many studies have examined granulosa cell steroidogenesis and its regulation, few have considered the contribution made by theca cells. In vitro androgen production by theca cells has been investigated in several species (pigs: May et al., 1992; Barbieri, 1994; cows: DemeterArlotto et al., 1993; sheep: Campbell et al., 1998). However, pig theca cells are of particular interest because in addition to androgen production, they are also capable of independent oestradiol synthesis (Evans et al., 1981; Tsang et al., 1985; Hunter et al., 1994, Miller et al., 1998) since they possess an active cytochrome $\mathrm{P} 450$ aromatase ( $\mathrm{P}^{4} 50_{\text {arom }}$ ) (Lautinicik et al., 1994; Meduri et al., 1996; Garrett and Guthrie, 1996, 1997). Studies in this laboratory demonstrated the presence in pig theca cells of $\mathrm{P} 40_{\text {arom }}$ mRNA by northern blot analysis (Miller et al., 1995) and the active $\mathrm{P}^{\mathrm{a}} 50_{\text {arom }}$ enzyme by

${ }^{*}$ Correspondence.

Received 9 August 1999 immunohistochemistry (Shores et al., 1997). Precisely how thecal oestradiol production is regulated in pigs is unclear and progress has been hampered by the lack of a suitable cell culture system. Serum is commonly added to culture systems to provide the complex mixture of nutrients, hormones and growth factors required by the cells. Unfortunately, this means that the exact requirements of a particular type of cell are unknown. In addition, the use of serum can result in spontaneous luteinization of the ovarian cells (Engelhardt et al., 1991; Conley et al., 1994; Picton et al., 1999) characterized by a loss of $\mathrm{P} 450_{\text {arom }}$ activity and increased progesterone synthesis.

Accordingly, a serum-free system for the culture of pig granulosa cells was developed in this laboratory (Picton et al., 1999) based on similar serum-free systems used for ruminants (Campbell et al., 1996; Gutiérrez et al., 1997a). In the pig system, granulosa cell $\mathrm{P} 450_{\text {arom }}$ activity and thus oestradiol synthesis were maintained throughout the culture period. Granulosa cells cultured in this serum-free system remained round and formed clumps, whereas in the 
presence of serum they became fibroblastic, forming monolayers on the plate surface. Therefore, morphologically, granulosa cells cultured under serum-free conditions were similar to their in vivo counterparts. It would be extremely valuable to develop a defined serum-free culture system for theca cells in which in vivo morphology, steroidogenesis and gonadotrophin responsiveness were maintained. This would allow investigation of the regulation of steroidogenesis by theca cells that maintain their follicular phase phenotype in culture.

The development of a defined serum-free culture system for pig theca cells, used in conjunction with the serum-free granulosa cell system, allows investigation of proposed theca-granulosa cell interactions using a co-culture that mimics in vivo conditions. An interaction between these types of cell is likely due to their close proximity and the need for the follicle to produce a co-ordinated response to a complex array of signals, such as gonadotrophins and growth factors. In the present study, the effect of theca-granulosa cell co-culture on oestradiol synthesis was investigated. Oestradiol was selected as an end point since it is the production of this hormone that ultimately triggers ovulation and because pig granulosa and theca cells are both capable of independent oestradiol production.

The aims of this study were: (i) to establish a physiologically relevant serum-free culture system for pig theca cells and to use it to study specific factors involved in the regulation of thecal steroidogenesis; and (ii) to establish a co-culture system to test the hypothesis that theca and granulosa cells interact, resulting in increased oestradiol production compared with the two types of cell cultured separately.

\section{Materials and Methods}

All chemicals were obtained from Sigma Chemical Company Ltd, Poole, unless otherwise stated.

\section{Cell collection}

Morphologically normal pig ovaries from sexually mature animals were obtained from a local abattoir and washed in pre-warmed $\left(37^{\circ} \mathrm{C}\right)$ dissection medium (EMEM with $25 \mathrm{mmol}$ HEPES $\mathrm{l}^{-1}$ plus $100 \mathrm{iu}$ penicillin $\mathrm{ml}^{-1}$, $0.1 \mathrm{ng}$ streptomycin $\mathrm{ml}^{-1}$ and $50 \mu \mathrm{g}$ gentamicin $\mathrm{ml}^{-1}$ (GibcoBRL, Paisley)) with $10 \mathrm{mg}$ amphotericin $\mathrm{B} \mathrm{ml}^{-1}$. Large, morphologically healthy (6-9 $\mathrm{mm}$ in diameter) follicles were dissected, the follicular fluid aspirated and the follicles were cut into four pieces in Dulbecco's PBS (DPBS) without calcium or magnesium. Granulosa cells were removed by gently scraping the inside of the follicle shells with a sterile plastic inoculation loop under a dissecting microscope followed by agitation through a plastic Pasteur pipette. The follicles were transferred to fresh DPBS and scraped again.

Granulosa cells were collected by centrifugation at $800 \mathrm{~g}$ for $10 \mathrm{~min}$ and washed twice in warm incubation medium (DMEM/Ham's F12 with 15 mmol HEPES ${ }^{-1}$ and $\mathrm{NaHCO}_{3}$ plus $3 \mathrm{mmol}$ L-glutamine $\mathrm{l}^{-1}, 100 \mathrm{iu}$ penicillin $\mathrm{ml}^{-1}, 0.1 \mathrm{ng}$ streptomycin $\mathrm{ml}^{-1}, 2.5 \mu \mathrm{g}$ transferrin $\mathrm{ml}^{-1}, 4 \mathrm{ng}$ sodium selenite $\mathrm{ml}^{-1}$ and $0.1 \%(\mathrm{w} / \mathrm{v})$ BSA (fraction $\mathrm{V}$ cell culture grade)). The number of viable granulosa cells before the start of culture was assessed using trypan blue exclusion and was $54 \pm 5 \%$.

After removal of granulosa cells, the theca layer was peeled away from the follicle shell using fine forceps under a dissecting microscope. Theca sheets from $\leqslant 20$ follicles were dispersed by incubation in a $10 \mathrm{ml}$ solution of $0.5 \%(\mathrm{w} / \mathrm{v})$ collagenase type II and $0.1 \%(\mathrm{w} / \mathrm{v})$ hyaluronidase type I-S in Hank's balanced salt solution with $20 \mathrm{mmol} \mathrm{HEPES} \mathrm{l}^{-1}$ and $5 \%$ fetal calf serum for a maximum of $30 \mathrm{~min}$ at $37^{\circ} \mathrm{C}$ in a shaking waterbath (Hunter and Armstrong, 1987; Ranson et al., 1997). The dispersed cells were washed twice in warm incubation medium. The number of viable theca cells before the start of culture was assessed using trypan blue exclusion and was $91 \pm 7 \%$.

For all cultures, the number of viable cells after $144 \mathrm{~h}$ was assessed by uptake of neutral red dye as described by Campbell et al. (1996) and Picton et al. (1999).

\section{Assessment of the purity of the theca cell preparation}

This procedure was based on the method of Kataoka et al. (1994) to confirm the purity of pig theca cell preparations. Both theca and granulosa cells were plated at $100 \times 10^{3}$ viable cells per well per $250 \mu \mathrm{l}$ in 96-well plates (Nunclon, Life Technologies Ltd). All wells contained incubation medium with $10 \mathrm{ng}$ bovine insulin $\mathrm{ml}^{-1}, 100 \mathrm{ng}$ Long R3 IGF-I $\mathrm{ml}^{-1}$ (media grade synthetic IGF-I analogue Gropep Pty Ltd, Adelaide), $100 \mathrm{ng}$ testosterone $\mathrm{ml}^{-1}$ and $10 \%$ fetal calf serum. The amount of fetal calf serum was reduced to $2.5 \%$ from 48-144 h. FSH (USDA-pFSH-I-2; LH contamination < 1\%) was added at 10 and $100 \mathrm{ng} \mathrm{ml}^{-1}$. The medium was changed every $48 \mathrm{~h}$ for $144 \mathrm{~h}$ and the spent medium frozen for subsequent radioimmunoassay for progesterone.

Removal of granulosa cells was confirmed by histological examination of scraped follicle shells (6-9 mm follicles, $n=$ 35). These were fixed in $4 \%(\mathrm{w} / \mathrm{v})$ paraformaldehyde solution and embedded in paraffin wax. Sections were cut at $5 \mu \mathrm{m}$ and stained by a standard haematoxylin and eosin protocol. Three random sections from each follicle were examined.

\section{Theca cell culture}

Theca cells were plated in serum-free medium at $50-150 \times 10^{3}$ viable cells per well per $250 \mu \mathrm{l}$ with a range of LH (0.01-1.0 ng ml-1; FSH contamination < 1\%), insulin (1, $10 \mathrm{ng} \mathrm{ml}^{-1}$ ) and Long R3 IGF-I (10, $100 \mathrm{ng} \mathrm{ml}^{-1}$, subsequently referred to as IGF-I) doses. Each culture was carried out three times with four replicates per treatment in each culture. Cultures were incubated at $37^{\circ} \mathrm{C}$ in a humidified atmosphere of $5 \% \mathrm{CO}_{2}$ in air for $144 \mathrm{~h}$; the medium was exchanged every $48 \mathrm{~h}$. Only $175 \mu \mathrm{l}$ of medium per well was exchanged slowly to reduce the disturbance of the cells. Spent medium was frozen at $-20^{\circ} \mathrm{C}$ until assayed for progesterone, androstenedione and oestradiol. 


\section{Co-culture}

A preliminary experiment was conducted to establish a suitable plating density for the co-cultures. Granulosa and theca cells were co-cultured in serum-free medium in a ratio of $4: 1$ at a total cell concentration of either $50 \times 10^{3}$ viable cells per well, that is $40 \times 10^{3}$ granulosa cells plus $10 \times 10^{3}$ theca cells, or $150 \times 10^{3}$ viable cells per well, that is $120 \times 10^{3}$ granulosa cells plus $30 \times 10^{3}$ theca cells. Control wells contained either 50 or $150 \times 10^{3}$ granulosa cells or 50 or $150 \times 10^{3}$ theca cells. All wells contained pre-warmed

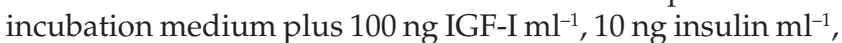
$0.01 \mathrm{ng} \mathrm{LH} \mathrm{ml}^{-1}$ (USDA-pLH-B2) and $1 \mathrm{ng} \mathrm{FSH} \mathrm{ml}^{-1}$ (USDApFSH-I-2). Wells containing granulosa cells only were supplemented with $100 \mathrm{ng}$ androstenedione $\mathrm{ml}^{-1}$. Oestradiol production at $48 \mathrm{~h}$ only was measured.

After the preliminary experiment, co-cultures were established with a total cell concentration of $50 \times 10^{3}$ viable cells per well $\left(40 \times 10^{3}\right.$ granulosa cells plus $10 \times 10^{3}$ theca cells). Control wells contained $50 \times 10^{3}$ granulosa or $50 \times 10^{3}$ theca cells. Wells containing granulosa cells only received either a 'physiological' dose or $100 \mathrm{ng}$ androstenedione $\mathrm{ml}^{-1}$. The physiological dose was the estimated amount of androstenedione produced by $10 \times 10^{3}$ theca cells based on measurements taken during theca cell cultures. During the first $48 \mathrm{~h}$, the dose was $5 \mathrm{ng}$ per well, from $48-96 \mathrm{~h} 2 \mathrm{ng}$ per well and from 96-144 h $1 \mathrm{ng}$ per well. Wells containing theca cells only and co-culture wells received either no androstenedione or $100 \mathrm{ng} \mathrm{ml}^{-1}$ was administered at all time points. Spent medium was collected every $48 \mathrm{~h}$ for $144 \mathrm{~h}$ and stored at $-20^{\circ} \mathrm{C}$ before assay for oestradiol.

Oestradiol production by co-cultures was compared with the sum of oestradiol produced by granulosa and theca cells cultured alone. The sum of oestradiol production was calculated by the addition of $20 \%$ of the measured oestradiol from the theca cell control wells $(20 \%$ is equivalent to $10 \times 10^{3}$ theca cells) to $80 \%$ of the measured oestradiol from granulosa cell control wells $\left(80 \%\right.$ is equivalent to $40 \times 10^{3}$ granulosa cells).

\section{Assays}

The concentrations of oestradiol, progesterone and androstenedione were measured in culture medium by radioimmunoassay as described by Grant et al. (1989) and Thomson et al. (1989). The limits of sensitivity and inter- and intra-assay coefficients of variation were, respectively, $1.1 \mathrm{pg}$ per tube, $14.6 \%$ and $6.6 \%$ for oestradiol; 15.5 pg per tube, $14.2 \%$ and $9.5 \%$ for progesterone; and $1.6 \mathrm{pg}$ per tube, $10.1 \%$ and $5.9 \%$ for androstenedione.

\section{Statistical analysis}

Hormone data from serum-free cultures were corrected for the residual media left in the wells when the media was exchanged at 48 and $96 \mathrm{~h}$, as described by Campbell et al. (1996). The values were expressed as production per 1000 viable cells per $48 \mathrm{~h}$. The number of viable cells at $48 \mathrm{~h}$ was considered to be the initial plating density. At $144 \mathrm{~h}$, the number of viable cells was that obtained using the neutral red dye method. The data were $\log (x+1)$ transformed to remove heterogeneity of variance before ANOVA using the Genstat statistical package. The pooled variance was used to calculate the standard error of the difference (SED) between two means. Replicate cultures were treated as blocks and treatment effects were considered significant at $P<0.05$. When indicated by ANOVA, individual treatment means were compared using Bonferroni's test.

\section{Results}

\section{Assessment of the purity of the theca cell preparation}

In the preliminary experiments, progesterone production during the final $48 \mathrm{~h}$ of culture was measured. FSH increased granulosa cell progesterone production in a dose-dependent manner. FSH doses of 0,10 and $100 \mathrm{ng} \mathrm{ml}^{-1}$ resulted in granulosa and theca cell log progesterone production of 1.47 , 1.73 and 1.83 (SED $0.05, P<0.001$ ) and $1.84,1.91$ and 1.85 (SED 0.06) ng per 1000 viable cells, respectively. Theca cell progesterone output was therefore unaffected by FSH. Further confirmation of removal of granulosa cells was demonstrated by the histology of the scraped follicle shells (Fig. 1a,b).

\section{Theca cell cultures}

In the main experiments, dispersed theca cells rapidly formed clumps of rounded cells in culture (Fig. 1c) similar to those observed in serum-free granulosa cell cultures. Steroidogenesis continued throughout the culture period. Initial plating density had a profound effect on theca cell steroidogenesis (Table 1). Oestradiol output was influenced by plating density at 48 and $144 \mathrm{~h}(P<0.001$ at both time points), as was androstenedione synthesis $(P<0.01$ at both time points). At $48 \mathrm{~h}$, oestradiol production per 1000 viable cells was highest at a density of $50 \times 10^{3}$ viable cells per well. This density resulted in 33\% more oestradiol than 75 and $100 \times 10^{3}$ viable cells and $80 \%$ more oestradiol than $150 \times 10^{3}$ viable cells $(P<0.001)$. After $144 \mathrm{~h}, 150 \times 10^{3}$ viable cells per well resulted in $50 \%$ lower oestradiol synthesis per cell than densities of 50,75 and $100 \times 10^{3}$ viable cells $(P<$ $0.001)$. Again, $50 \times 10^{3}$ viable cells per well produced the most oestradiol per 1000 cells.

At $48 \mathrm{~h}$, androstenedione production was 2-4.5-fold higher at $50 \times 10^{3}$ viable cells than at other plating densities $(P<0.001)$. Densities of 75 and $100 \times 10^{3}$ viable cells were similar and both were at least twofold higher than $150 \times 10^{3}$ viable cells. Androstenedione production was 2.4 times higher at 75 than at 50 and $150 \times 10^{3}$ viable cells after $144 \mathrm{~h}$ in culture $(P<0.01)$. All other plating densities were similar.

At $48 \mathrm{~h}$, oestradiol production was not altered by LH dose (Fig. 2a). After $144 \mathrm{~h}$ in culture, all LH doses increased oestradiol production by an average twofold above control values $(P<0.05$; Fig. 2 b) .

Androstenedione production was stimulated by 
Table 1. Effect of plating density (50-150 × $10^{3}$ viable cells per well) on pig theca cell steroidogenesis after 48 and $144 \mathrm{~h}$ in defined serum-free culture

\begin{tabular}{|c|c|c|c|c|}
\hline \multirow{2}{*}{$\begin{array}{l}\text { Initial plating density } \\
\left(\times 10^{3} \text { viable cells }\right.\end{array}$} & \multicolumn{2}{|c|}{$\begin{array}{l}\text { Log oestradiol production } \\
\text { (pg per } 10^{3} \text { viable cells per } 48 \mathrm{~h} \text { ) }\end{array}$} & \multicolumn{2}{|c|}{$\begin{array}{l}\text { Log androstenedione production } \\
\text { (pg per } 10^{3} \text { viable cells per } 48 \mathrm{~h} \text { ) }\end{array}$} \\
\hline & $48 \mathrm{~h}$ & $144 \mathrm{~h}$ & $48 \mathrm{~h}$ & $144 \mathrm{~h}$ \\
\hline 50 & $1.61^{\mathrm{a}}$ & $1.54^{\mathrm{a}}$ & $2.48^{\mathrm{a}}$ & $2.69^{a}$ \\
\hline 75 & $1.52^{b}$ & $1.48^{\mathrm{a}}$ & $2.19^{b}$ & $3.11^{\mathrm{b}}$ \\
\hline 100 & $1.48^{\mathrm{b}}$ & $1.51^{\mathrm{a}}$ & $2.11^{b}$ & $2.76^{\mathrm{ab}}$ \\
\hline 150 & $1.34^{\mathrm{c}}$ & $1.34^{\mathrm{b}}$ & $1.82^{\mathrm{c}}$ & $2.70^{\mathrm{a}}$ \\
\hline SED & 0.03 & 0.04 & 0.05 & 0.14 \\
\hline
\end{tabular}

Data were log transformed before ANOVA and values represent the mean of three separate cultures each containing four wells per treatment.

Values in the same column with different superscripts are significantly different at $P<0.05$.

increasing LH doses at all time points $(P<0.001$; Fig. $2 \mathrm{c}, \mathrm{d})$. At $48 \mathrm{~h}, 0.5 \mathrm{ng} \mathrm{LH} \mathrm{ml} \mathrm{m}^{-1}$ was required to stimulate androstenedione production above control values; however, by $144 \mathrm{~h}$ the $\mathrm{LH}$ dose required to achieve an increase had decreased to $0.05 \mathrm{ng} \mathrm{ml}^{-1}$. The magnitude of this increase also changed from 1.7-fold at $48 \mathrm{~h}$ to over fourfold at $144 \mathrm{~h}$.

$\mathrm{LH}$ doses of $0.05 \mathrm{ng} \mathrm{ml}^{-1}$ or more increased progesterone production at $48 \mathrm{~h}(P<0.001$; Fig. $2 \mathrm{e})$. $\mathrm{LH}$ at $1 \mathrm{ng} \mathrm{ml}^{-1}$ increased progesterone by more than 3.5 -fold over control values. After $144 \mathrm{~h}$ in culture, LH dose no longer affected progesterone production (Fig. 2f).

IGF-I increased oestradiol and androstenedione production at $144 \mathrm{~h} \quad(P<0.001$ for both hormones). Oestradiol output was increased by an IGF-I dose of $10 \mathrm{ng}$ $\mathrm{ml}^{-1}\left(P<0.001\right.$; Fig. 3a) but $100 \mathrm{ng} \mathrm{ml}^{-1}$ IGF-I was required to raise androstenedione above control values $(P<0.001$; Fig. 3b).

Insulin did not influence oestradiol output (Fig. 3a) or androstenedione production (Fig. 3b). However, there was an interaction between IGF-I and insulin in terms of androstenedione production at $144 \mathrm{~h}(P<0.05)$. The combination of $10 \mathrm{ng}$ insulin $\mathrm{ml}^{-1}$ with $100 \mathrm{ng}$ IGF-I ml $\mathrm{m}^{-1}$ resulted in 12-fold more androstenedione than $10 \mathrm{ng}$ insulin $\mathrm{ml}^{-1}$ with $10 \mathrm{ng}$ IGF-I ml-1 $(P<0.05)$.

\section{Co-cultures}

The preliminary experiment revealed that oestradiol production by co-cultures was also influenced by initial plating density. The cells in low density co-cultures (total of $50 \times 10^{3}$ viable cells per well) produced almost twice as much oestradiol per cell compared with those in high density co-cultures (total of $150 \times 10^{3}$ viable cells per well) $\left(P<0.001\right.$; Fig. 4). Therefore, a plating density of $50 \times 10^{3}$ viable cells per well $\left(10 \times 10^{3}\right.$ viable theca cells plus $40 \times 10^{3}$ viable granulosa cells) was used for subsequent co-culture experiments.

Mixed co-cultures produced more oestradiol than the sum of separate theca and granulosa cell cultures $(P<0.001$; Fig. 5). Androstenedione was added to wells containing granulosa cells only at a physiological dose (calculated to be the same as the amount of androstenedione produced by the theca cells in the mixed wells, that is $10 \times 10^{3}$ viable cells per well) or at $100 \mathrm{ng} \mathrm{ml}^{-1}$ (the dose commonly used in previous co-culture studies). The higher androstenedione dose (100 ng $\mathrm{ml}^{-1}$ ) was also added to mixed co-cultures and wells containing theca cells only to test whether any interaction occurred in the presence of additional androgen substrate. With either dose of androstenedione, co-cultures produced more oestradiol than the sum of separate cultures $(P<0.001)$. Addition of $100 \mathrm{ng}$ androstenedione $\mathrm{ml}^{-1}$ increased overall oestradiol concentrations $(P<0.001)$ but did not alter the occurrence of an interaction. Co-culture wells treated with the physiological dose had threefold higher oestradiol than the sum, whereas co-cultures treated with $100 \mathrm{ng}$ androstenedione $\mathrm{ml}^{-1}$ were 4 .4-fold higher than the sum.

\section{Discussion}

In the present study, the purity of the theca cell preparation was confirmed biochemically using the response of ovarian cells to FSH. This experiment was conducted before the development of the serum-free culture system and was based on the validation method of Kataoka et al. (1994) using medium containing serum. Histological examination of scraped follicle shells confirmed the removal of granulosa cells. Purity is fundamental to ensuring any observed response to culture conditions is purely thecal in origin (Haney and Schomberg, 1981). Despite this, many reports do not mention any attempts to ensure purity in theca cell preparations (Morley et al., 1989; Sirois et al., 1991; Kotsuji and Tominaga, 1994; Armstrong et al., 1996).

Theca sheets were digested to release individual cells for culture, but within $24 \mathrm{~h}$ these cells had formed clumps attached loosely to the plate by a flattened 'stalk'. The cells within these clumps were rounded, resembling the in vivo condition, and remained so throughout the culture period. Morphology may be a good indicator of function. An ultrastructural study of bovine granulosa cells (Gutiérrez et al., 1997b) revealed that the round cells present in serum-free medium retained organelles characteristic of granulosa cells in vivo and continued to secrete oestradiol. Granulosa cells cultured with serum became flattened and ceased oestradiol production. This finding indicates that the theca cells within 

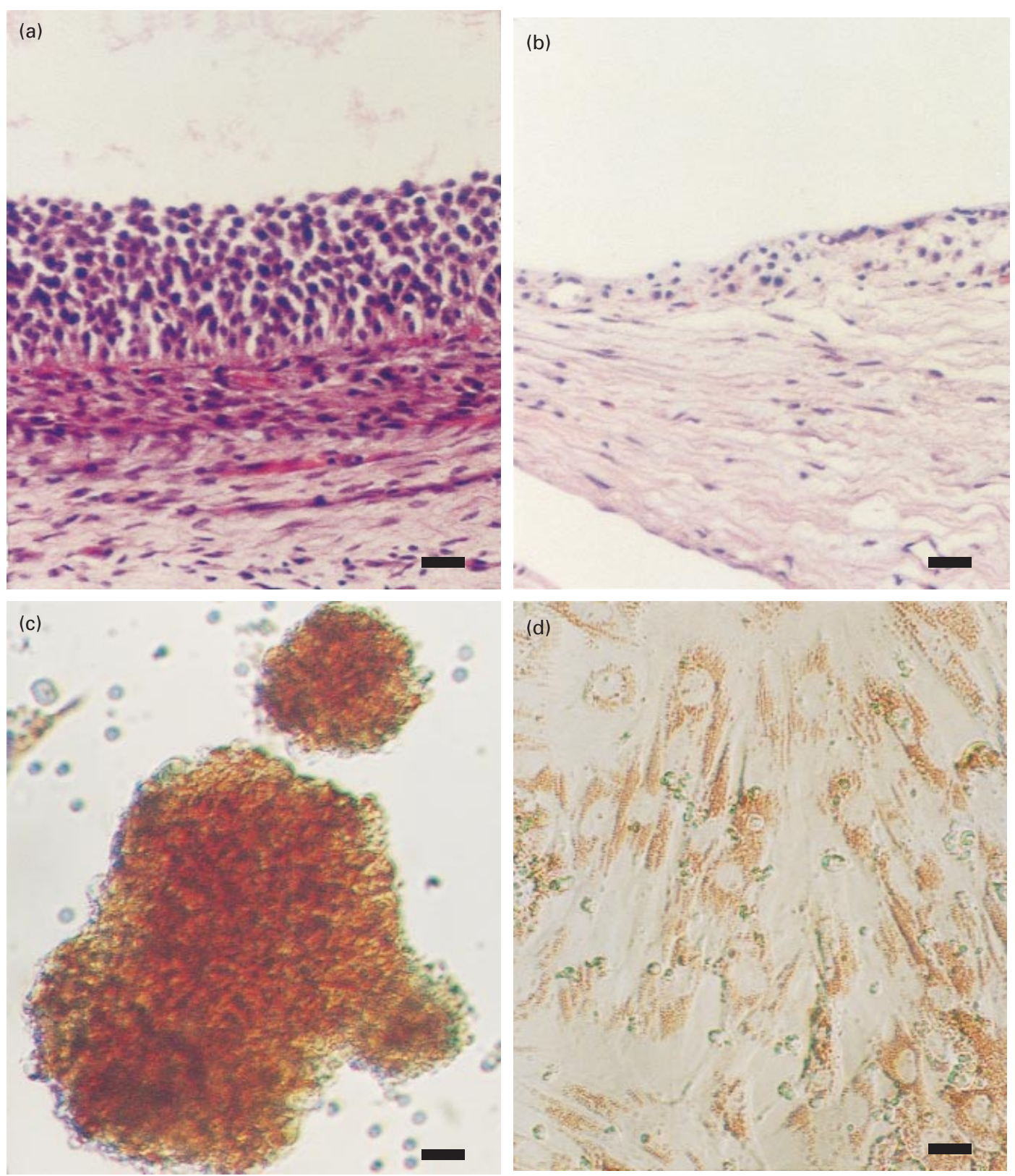

Fig. 1. Large (6-9 mm in diameter) healthy pig follicles before (a) and after (b) the removal of granulosa cells. Sections were stained with haematoxylin and eosin. Comparison of the morphology of theca cells when cultured in serum-free medium (c) and with fetal calf serum (d) for $144 \mathrm{~h}$. Theca cells were collected from large (6-9 mm in diameter) healthy pig follicles. Cells were stained with neutral red dye. Scale bars represent $20 \mu \mathrm{m}$.

the clumps would retain $\mathrm{P} 450$ 17 $\alpha$-hydroxylase $\left(\mathrm{P} 40_{17 \alpha}\right)$ and P450 arom activities, whereas the 'stalk' cells would lose them. Further work is required to confirm this observation.

Initial plating density was very important to steroid production. Precisely how density influences steroidogenesis is unclear, but Campbell et al. (1998) suggested that it may have a role in maintaining $\mathrm{P}^{4} 50_{17 \alpha}$ activity. The detrimental effects of high plating density indicate that the production of metabolic waste products may adversely affect steroidogenesis. The optimum density for pig theca cells in the present system is different from that of pig granulosa cells in a similar serum-free system (50 and $150 \times 10^{3}$ viable cells per well, respectively, Picton et al., 1999). This difference may reflect observed differences in the numbers of each type of cell present within the follicle (Stoklosowa et al., 1982; Kokia et al., 1992) and was an important consideration in the development of a physiologically relevant co-culture system.

Theca cells were extremely sensitive to LH and the concentrations of LH used in this study are low compared with those used by other workers in theca cell culture (pigs: $250 \mathrm{ng} \mathrm{ml}^{-1}$, Morley et al., 1989, Engelhardt et al., 1991; $25 \mathrm{ng}$ $\mathrm{ml}^{-1}$, Barbieri, 1994; $20 \mathrm{ng} \mathrm{ml}^{-1}$, Caubo et al., 1989; cows: $100 \mathrm{ng} \mathrm{ml}^{-1}$, Bao et al., 1995). Berndtson et al. (1995) suggested that high concentrations of gonadotrophins (32-256 $\left.\mathrm{ng} \mathrm{ml}^{-1}\right)$ 

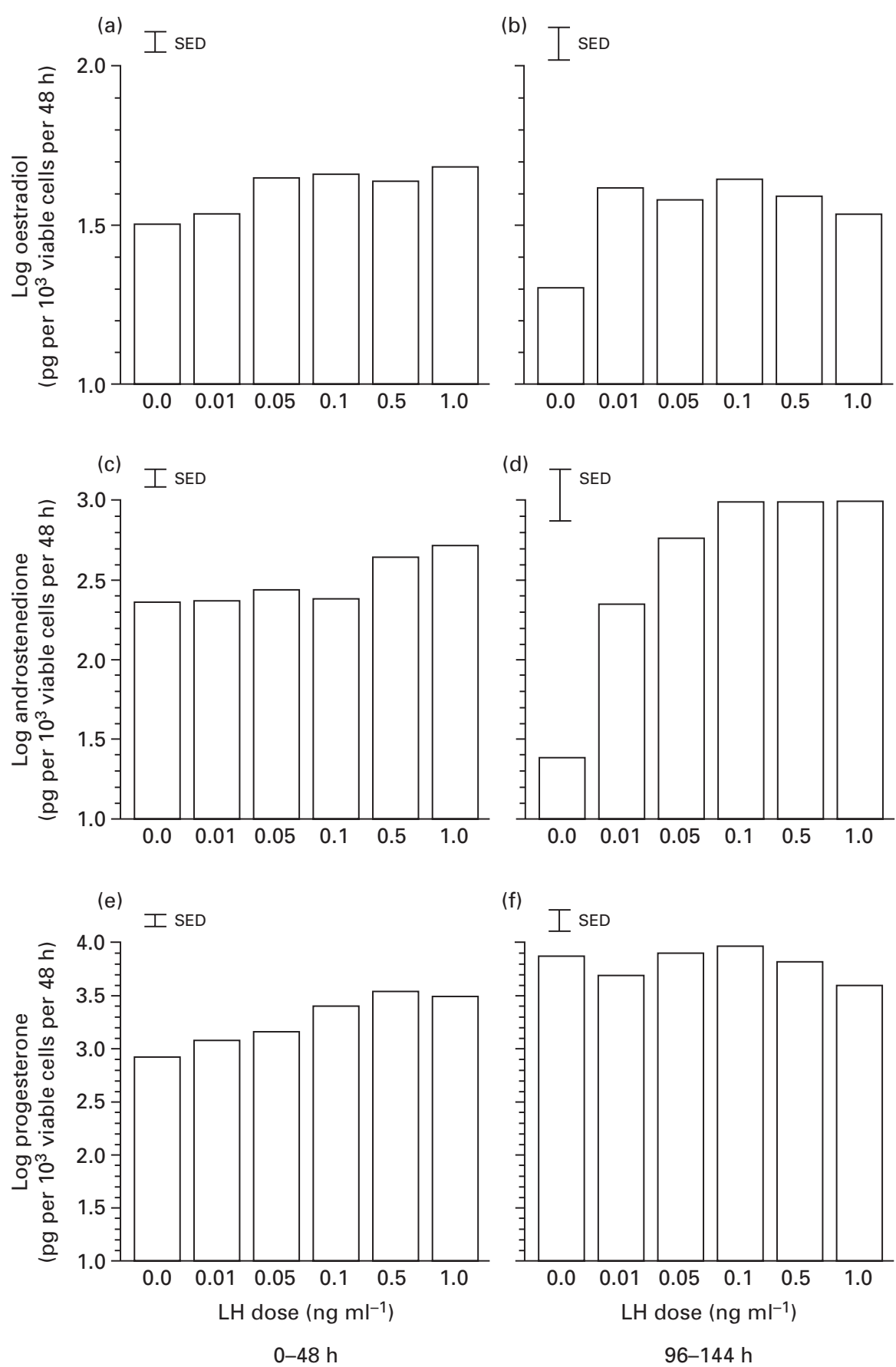

Fig. 2. The effect of LH dose on oestradiol $(a, b)$, androstenedione $(c, d)$ and progesterone $(e, f)$ production by pig theca cells after $48 \mathrm{~h}(\mathrm{a}, \mathrm{c}, \mathrm{e})$ and $144 \mathrm{~h}(\mathrm{~b}, \mathrm{~d}, \mathrm{f})$ in defined serum-free culture. The data were log transformed before ANOVA and are expressed as production per $10^{3}$ viable cells. Values are the mean of three separate cultures each containing four wells per treatment.

caused bovine ovarian cells to luteinize. Similarly, Armstrong et al. (1996) reported that LH doses $\geqslant 10 \mathrm{ng} \mathrm{ml}^{-1}$ increased progesterone and decreased androstenedione production by ovine theca cells. Therefore, some earlier reports may be confounded by the high gonadotrophin concentrations causing the cells to luteinize. In the present study, progesterone output was on average 3.6-fold higher at
$144 \mathrm{~h}$ than at $48 \mathrm{~h}$. Campbell et al. (1998) also noted a fourfold increase in progesterone concentrations with time in culture using ovine theca cells and Picton et al. (1999) observed a sixfold increase in pig granulosa cell progesterone output over time. Despite the increase in progesterone concentrations, several factors show that in the present study the theca cells did not luteinize fully. Androstenedione and 

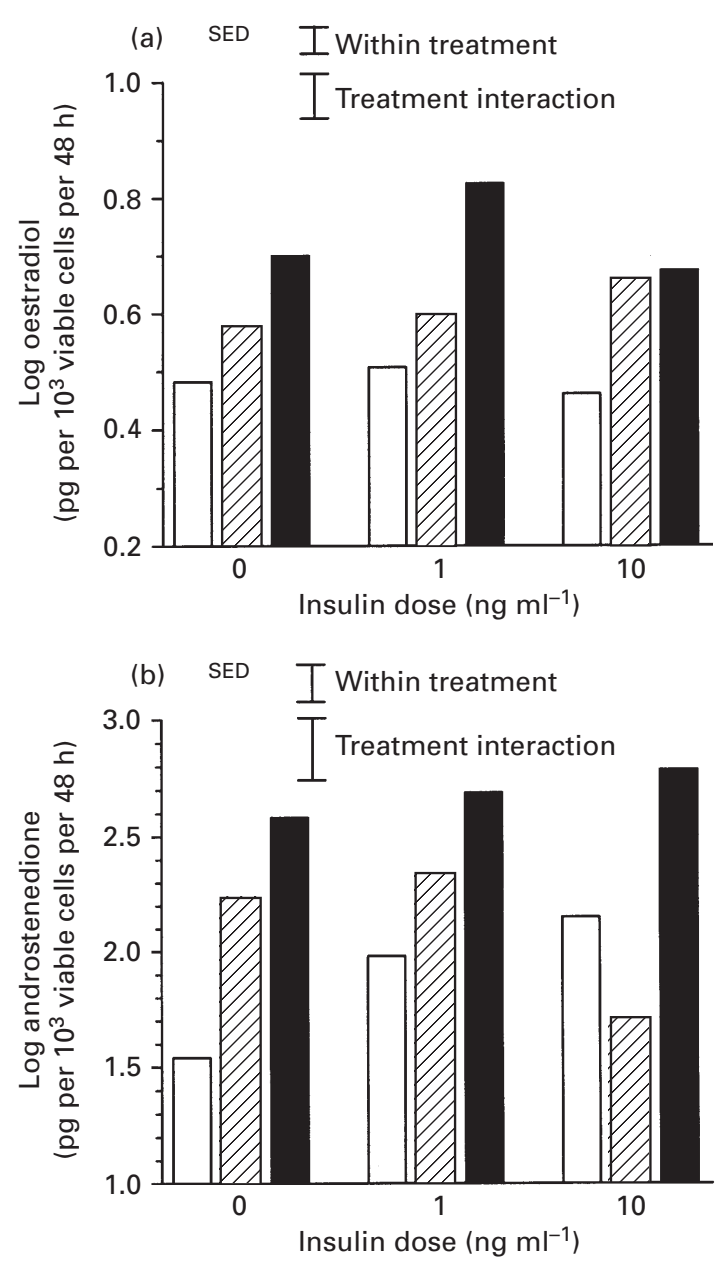

Fig. 3. The effect of insulin-like growth factor I (IGF-I) and insulin doses on oestradiol (a) and androstenedione (b) production by pig theca cells after $144 \mathrm{~h}$ in defined serum-free culture. IGF-I doses: 0 $(\square), 10$ (四) and $100 \mathrm{ng} \mathrm{ml}^{-1}(\mathbf{\square})$. The data were log transformed before ANOVA and are expressed as production per $10^{3}$ viable cells. Values are the mean of three separate cultures each containing four wells per treatment.

oestradiol synthesis continued throughout culture and production remained responsive to LH. Oestradiol production by pig luteal cells in vitro is unresponsive to LH and hCG (Pitzel et al., 1988). In addition, the cells maintained the same follicular phase morphology during culture. In the present study, after establishing that the theca cells did not luteinize in the serum-free culture system, the subsequent experiments concentrated on the influence of the additives on oestradiol and androstenedione synthesis.

Increasing LH dose stimulated androstenedione synthesis at all time points. In the growing follicle, theca cells under the influence of LH provide androgen substrate (Ryan, 1979; Evans et al., 1981). In the current system, theca cells behaved as in vivo by responding to $\mathrm{LH}$ and producing androstenedione. The sensitivity of the cells to LH increased tenfold with time, indicating an increase in the number or sensitivity of thecal LH receptors over the culture period.

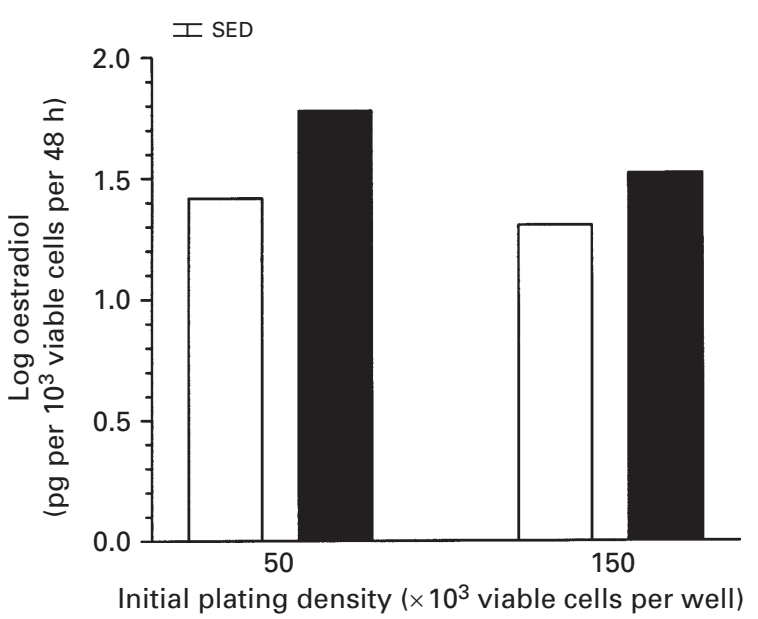

Fig. 4. Oestradiol production by pig granulosa and theca cells after $48 \mathrm{~h}$ in serum-free medium. Cells were plated in a ratio of granulosa to theca cells of 4:1 at a total density of either 50 or $150 \times 10^{3}$ viable cells per well. The data were log transformed before ANOVA and are expressed as production per $10^{3}$ viable cells. Data are from a single preliminary experiment containing four wells per treatment. Coculture ( $\square)$, sum $(\square)$.

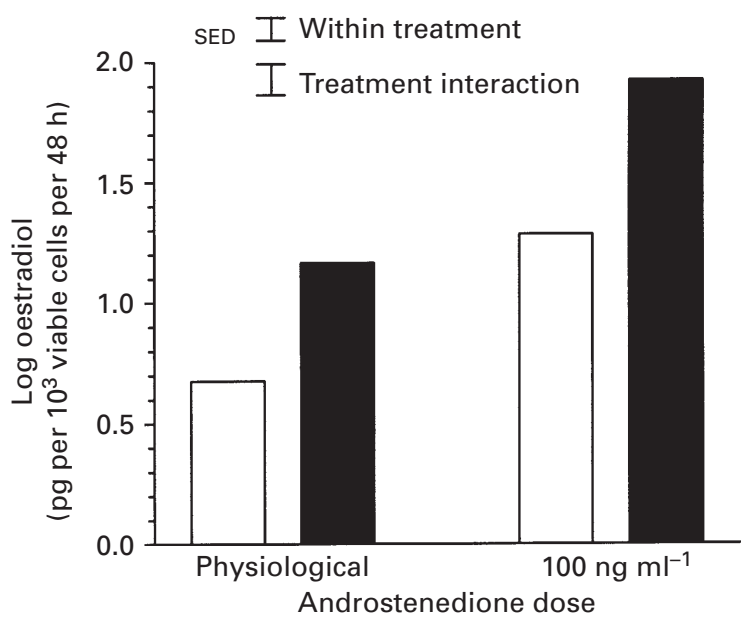

Fig. 5. Oestradiol production by pig granulosa and theca cells cultured separately $(\square)$ or as co-cultures $(\square)$ after $144 \mathrm{~h}$ in serum-free medium. The data were log transformed before ANOVA and are expressed as production per $10^{3}$ viable cells. Values are from three individual cultures each containing four wells per treatment.

However, oestradiol output was less sensitive to LH dose. At $48 \mathrm{~h}$, oestradiol production was not significantly increased by LH. After $144 \mathrm{~h}, \mathrm{LH}$ increased oestradiol synthesis but the response was not dose dependent. This finding shows that increased oestradiol production was not simply a result of increased androstenedione substrate availability. Furthermore, experiments using this culture system demonstrated that the addition of exogenous androstenedione did not increase thecal oestradiol output (E. Shores, unpublished). 
The high levels of statistical significance resulting from analysis of the androstenedione data and the dosedependent response indicate that LH plays a greater role in the regulation of androstenedione than oestradiol production. Furthermore, these observations imply that in vivo, the primary role of theca cells is androgen production, which is tightly regulated by LH. Oestradiol synthesis by theca cells is a secondary role, which does not warrant such strong LH control. Progesterone production at $48 \mathrm{~h}$ was increased by LH doses as low as $0.05 \mathrm{ng} \mathrm{ml}^{-1}$. Doses of $0.1,0.5$ and $1.0 \mathrm{ng} \mathrm{ml}^{-1}$ produced similar responses, which were on average 3.5-fold more than control values. Increased progesterone production may reflect increased demand for substrate for conversion to androstenedione by the theca cells.

IGF-I affected oestradiol and androstenedione output. However oestradiol synthesis was increased by a lower IGF-I dose $\left(10 \mathrm{ng} \mathrm{ml}^{-1}\right)$ than androstenedione production $\left(100 \mathrm{ng} \mathrm{ml}^{-1}\right)$. Therefore, IGF-I may act downstream of androstenedione production initially, possibly directly on P450 arom. Insulin alone did not influence oestradiol synthesis despite previous reports that insulin increased hormone production by pig theca cells in vitro $\left(1 \mathrm{mg} \mathrm{ml}^{-1}\right.$, Morley et al., 1989; 10-40 mg ml $\mathrm{mg}^{-1}$, Stein et al., 1990; $250 \mathrm{ng} \mathrm{ml}^{-1}$, Barbieri, 1994). However, these studies used supraphysiological doses that were much higher than those in the present study. Nevertheless, in the current study, insulin acted synergistically with IGF-I (10 ng insulin $\mathrm{ml}^{-1}$ plus $100 \mathrm{ng}$ IGF-I ml-1) to increase androstenedione production.

Within the follicle, the number of granulosa and theca cells are not equal. Stoklosowa et al. (1982) and Kokia et al. (1992) suggested a ratio of theca to granulosa cells of $1: 4$. In vivo estimates of the number of theca cells within a follicle are scarce. Downey and Driancourt (1994) reported a ratio of granulosa to theca cells of 2.5:1 in pig follicles. In the present study, total recovery rates per follicle revealed a ratio of theca to granulosa cells of 1:5. Importantly, the ratio adopted in the current experiments is more similar to in vivo conditions than the 1:1 ratio used in some earlier work (Tsang et al., 1985).

Co-culture increased oestradiol synthesis twofold compared with the sum oestradiol produced after $48 \mathrm{~h}$. However, after $144 \mathrm{~h}$, the magnitude of the interactive stimulation of oestradiol synthesis had increased to approximately threefold. Stoklosowa et al. (1982) reported a similar increase in the difference in oestradiol production between co-cultures and cultures of a single type of cell (1.4fold after $48 \mathrm{~h}, 2.5$-fold after $144 \mathrm{~h}$ ). This finding indicates that the cells become more sensitive to the factor or factors responsible for the interaction as time in culture progresses. Similarly, theca cells become increasingly sensitive to LH as time in culture progresses (see above; also ovine theca cells, Campbell et al., 1998).

In the present study, androstenedione was added to the cells containing granulosa cells only at a dose similar to that produced by theca cells in co-cultures (1-5 ng per well). A dose of $100 \mathrm{ng} \mathrm{ml}^{-1}$ (that is, $25 \mathrm{ng}$ per well) was compared with the physiological doses to investigate whether higher doses of androgen changed the observed interaction. Addition of more androstenedione increased overall oestradiol production by the co-cultures but did not influence the presence or size of the theca-granulosa cell interaction at $48 \mathrm{~h}$. By $144 \mathrm{~h}$, the higher androstenedione dose increased the size of the interactive increase in oestradiol output by co-cultures over the sum of individual cultures. This finding indicates increased sensitivity of the cells at the end of culture. Further work is required to identify the factor or factors responsible for the thecagranulosa cell interaction. The interaction may be mediated by growth factors produced by one or both types of cell. For example, granulosa-derived inhibin and IGF-I increase LHstimulated androgen production by theca cells in rats (Zachow and Magoffin, 1995). The use of intraovarian factors means that the influences of the gonadotrophins can be modulated to achieve a wider range of more subtle effects than would be possible with just two messengers (Kotsuji and Tominaga, 1994; Armstrong and Webb, 1997).

Why should granulosa and theca cells interact? Evidence from other organs of the body shows that mesenchymalepithelial cell interactions are very common, especially in those organs in which function follows cyclic patterns (Kotsuji and Tominaga, 1994; Parrott and Skinner, 1998). The ovary is an excellent example of such an organ with the mesenchymal-derived theca cells across a basement membrane from the epithelial-derived granulosa cells. The close proximity of granulosa and theca cells, together with the need to co-ordinate a cycle of growth and function implies a requirement for cell-cell communication. The current study demonstrates theca-granulosa cell interactions using a culture system designed to mimic closely in vivo conditions.

In conclusion, the present study demonstrates the development of a physiological serum-free culture system for pig theca cells in which in vivo morphology, steroidogenesis and gonadotrophin responsiveness are maintained. High initial plating density was detrimental to steroidogenesis. Theca cells were extremely sensitive to LH, becoming more sensitive with time in culture. Androstenedione production was regulated strongly by LH, whereas oestradiol synthesis was more sensitive to IGF-I dose. Theca and granulosa cells interacted in co-culture, resulting in increased oestradiol production in a system that mimicked in vivo conditions in terms of cell ratio and androgen availability. This culture system will enable further studies aimed at understanding the complex mechanisms involved in follicular development and steroidogenesis.

This work was supported by the BBSRC. Thanks are extended to D. G. Bolt, USDA, for the provision of pig gonadatrophins and to B. Cook for the androstenedione radioactive label.

\section{References}

Armstrong DG and Webb R (1997) Ovarian follicular dominance: the role of intraovarian growth factors and novel proteins Reviews of Reproduction 2 139-146

Armstrong DG, Hogg CO, Campbell BK and Webb R (1996) Insulin-like growth factor (IGF)-binding protein production by primary cultures of ovine granulosa and theca cells. The effects of IGF-I, gonadotropin, and follicle size Biology of Reproduction 55 1163-1171

Bao B, Thomas MG, Griffith MK, Burghardt RC and Williams GL (1995) Steroidogenic activity, insulin-like growth factor-1 production, and proliferation of granulosa and theca cells obtained from dominant 
preovulatory and non-ovulatory follicles during the bovine estrous cycle: effects of low-density and high-density lipoproteins Biology of Reproduction 53 1271-1279

Barbieri RL (1994) Insulin stimulates androgen accumulation in incubations of minced porcine theca Gynecologic and Obstetric Investigation 37 265-269

Berndtson AK, Vincent SE and Fortune JE (1995) Low and high concentrations of gonadotrophins differentially regulate hormone production by theca interna and granulosa cells from bovine preovulatory follicles Biology of Reproduction 52 1334-1342

Campbell BK, Scaramuzzi RJ and Webb R (1996) Induction and maintenance of oestradiol and immunoreactive inhibin production with FSH by ovine granulosa cells cultured in serum-free media Journal of Reproduction and Fertility 106 7-16

Campbell BK, Baird DT and Webb R (1998) Effects of dose of LH on androgen production and luteinization of ovine theca cells cultured in a serum-free system Journal of Reproduction and Fertility 112 69-77

Caubo B, deVinna RS and Tonetta SA (1989) Regulation of steroidogenesis in cultured porcine theca cells by growth factors Endocrinology 125 321-326

Conley AJ, Howard HJ, Slanger WD and Ford JJ (1994) Steroidogenesis in the preovulatory porcine follicle Biology of Reproduction 51 655-661

Demeter-Arlotto M, Rainey WE and Simpson ER (1993) Maintenance and regulation of $17 \alpha$-hydroxylase expression by bovine thecal cells in primary culture Endocrinology 132 1353-1358

Downey BR and Driancourt MA (1994) Morphological and functional characteristics of preovulatory follicles in Large White and Meishan gilts Journal of Animal Science 72 2099-2106

Engelhardt H, Gore-Langton RE and Armstrong DT (1991) Luteinization of porcine thecal cells in vitro. Molecular and Cellular Endocrinology 75 237-245

Evans G, Dobias M, King GJ and Armstrong DT (1981) Estrogen, androgen, and progesterone biosynthesis by theca and granulosa of preovulatory follicles in the pig Biology of Reproduction 25 673-682

Garrett WM and Guthrie HD (1996) Expression of androgen receptors and steroidogenic enzymes in relation to follicular growth and atresia following ovulation in pigs Biology of Reproduction 55 949-955

Garrett WM and Guthrie HD (1997) Steroidogenic enzyme expression during preovulatory follicle maturation in pigs Biology of Reproduction 56 1424-1431

Genstat Committee (1987) Genstat 5 Reference Manual Oxford University Press, Oxford, UK

Grant SA, Hunter MG and Foxcroft GR (1989) Morphological and biochemical characteristics during ovarian follicular development in the pig Journal of Reproduction and Fertility 86 171-183

Gutiérrez CG, Campbell BK and Webb R (1997a) Development of a longterm bovine granulosa cell culture system: induction and maintenance of estradiol production, response to follicle-stimulating hormone, and morphological characteristics Biology of Reproduction 56 608-616

Gutiérrez CG, Glazyrin AL, Robertson GW, Campbell BK, Gong JG, Bramley TA and Webb R (1997b) Ultra-structural characteristics of bovine granulosa cells associated with maintenance of oestradiol production in vitro. Molecular and Cellular Endocrinology 134 51-58

Haney AF and Schomberg DW (1981) Estrogen and progesterone production by developing porcine follicles in vitro: evidence for estrogen formation by theca Endocrinology 109 971-977

Hunter MG and Armstrong DT (1987) Oestrogens inhibit steroid production by dispersed porcine thecal cells Molecular and Cellular Endocrinology 50 $165-170$

Hunter MG, Biggs C, Pickard AR and Faillace LS (1994) Differences in follicular aromatase activity between Meishan and Large-White hybrid gilts Journal of Reproduction and Fertility 101 139-144

Kataoka N, Taii S, Kita M and Mori T (1994) Preparation of highly purified porcine theca cells Journal of Reproduction and Fertility 102 73-79

Kokia E, Hurwitz A, Ricciarelli E, Tedeschi C, Resnick CE, Mitchell MD and Adashi EY (1992) Interleukin-1 stimulates ovarian prostaglandin biosynthesis: evidence for heterologous contact independent cell-cell interaction Endocrinology 130 3095-3097
Kotsuji F and Tominaga T (1994) The role of granulosa and theca cell interactions in ovarian structure and function Microscopy Research and Technique 27 97-107

Lautincik J, Kolodzieyski L, Elias V, Hyttel P, Osawa Y and Sirotkin A (1994) Immunocytochemical localization of aromatase in the ovary of superovulated cattle, pigs and sheep Acta Veterinaria Scandinavica 35 185-191

May JV, Bridge AJ, Gotcher ED and Gangrade BK (1992) The regulation of porcine theca cell proliferation in vitro: synergistic actions of epidermal growth factor and platelet-derived growth factor Endocrinology 131 689-697

Meduri G, Vu Hai MT, Jolivet A, Takemori S, Kominami S, Driancourt MA and Milgrom E (1996) Comparison of cellular distribution of LH receptors and steroidogenic enzymes in the porcine ovary Journal of Endocrinology 148 435-446

Miller AT, Picton HM, Simpson ER and Hunter MG (1995) Investigation of steroidogenic enzyme expression in follicles from Meishan and LargeWhite sows Journal of Reproduction and Fertility Abstract Series 1675

Miller AT, Picton HM, Craigon J and Hunter MG (1998) Follicle dynamics and aromatase activity in high-ovulating Meishan sows and in Large-White hybrid contemporaries Biology of Reproduction 58 1372-1378

Morley P, Calaresu FR, Barbe GJ and Armstrong DT (1989) Insulin enhances luteinizing hormone-stimulated steroidogenesis by porcine theca cells Biology of Reproduction 40 735-743

Parrott JA and Skinner MK (1998) Thecal cell-granulosa cell interactions involve a positive feedback loop among keratinocyte growth factor, hepatocyte growth factor, and Kit ligand during ovarian follicular development Endocrinology 139 2240-2245

Picton HM, Campbell BK and Hunter MG (1999) Maintenance of oestradiol production and expression of cytochrome P450 aromatase enzyme mRNA in long-term serum-free cultures of pig granulosa cells Journal of Reproduction and Fertility 115 67-77

Pitzel L, Probst I, Jarry H and Wuttke W (1988) Inhibitory effect of oxytocin and vasopressin on steroid release by cultured porcine luteal cells Endocrinology 122 1780-1785

Ranson EJ, Picton HM and Hunter MG (1997) Effects of testosterone and oestradiol on $[3 \mathrm{H}]$-thymidine incorporation by porcine granulosa and theca cells Animal Reproduction Science $47229-236$

Ryan KJ (1979) Granulosa-thecal cell interaction in ovarian steroidogenesis Journal of Steroid Biochemistry 11 799-800

Shores EM, Picton HM, Harada N and Hunter MG (1997) Comparison of the distribution of steroidogenic enzymes and hormone production during follicular development in the pig Journal of Reproduction and Fertility Abstract Series 19118

Sirois J, Kimmich TL and Fortune JE (1991) Steroidogenesis by equine preovulatory follicles: relative roles of theca interna and granulosa cells Endocrinology 128 1159-1166

Stein AL, diZerega GS and Tonetta SA (1990) Steroidogenesis in porcine follicle cells cultured in serum-free media Gynecologic and Obstetric Investigation 29 285-288

Stoklosowa S, Gregoraszczuk E and Channing CP (1982) Estrogen and progesterone secretion by isolated cultured porcine thecal and granulosa cells Biology of Reproduction 26 943-952

Thomson S, Wallace AM and Cook B (1989) A ${ }^{125}$ I-radioimmunoassay for measuring androstenedione in serum and in blood-spot samples from neonates Clinical Chemistry 35 1706-1712

Tsang BK, Ainsworth L, Downey BR and Marcus GJ (1985) Differential production of steroids by dispersed granulosa and theca interna cells from developing preovulatory follicles of pigs Journal of Reproduction and Fertility 74 459-471

Zachow RJ and Magoffin DA (1995) Granulosa cell modulation of luteinizing hormone dependent androgen production by ovarian theca-interstitial cells: a temporal switch from suppression to augmentation stimulated by follicle stimulating hormone in vitro. Biology of Reproduction 53 758-765 